\title{
A Survey of the Structures of Mycolic Acids in Corynebacterium and Related Taxa
}

\author{
By M. D. COLLINS, ${ }^{*} \dagger$ M. GOODFELLOW ${ }^{2}$ AND D. E. MINNIKIN ${ }^{3}$ \\ ${ }^{1}$ Department of Microbiology, School of Medicine and Biological Sciences, The University, \\ Leicester LE1 7RH, U.K. \\ ${ }^{2}$ Department of Microbiology, The Medical School, The University, \\ Newcastle upon Tyne NE1 7RU, U.K. \\ ${ }^{3}$ Department of Organic Chemistry, The University, Newcastle upon Tyne NE1 7RU,U.K.
}

(Received 19 December 1980; revised 25 May 1981)

\begin{abstract}
Acid methanolysates of 104 strains of coryneform and related bacteria were examined for mycolic acids by thin-layer chromatography and mass spectrometry. The mycolic acids of Corynebacterium sensu stricto strains were not uniform in size and structure, and considerable variation existed within the approximate limiting range of $C_{22}$ to $C_{36}$. Two species, Corynebacterium bovis and 'Corynebacterium mycetoides', were particularly distinctive; the former had exceptionally low molecular weight mycolic acids $\left(\mathrm{C}_{22}\right.$ to $\left.\mathrm{C}_{32}\right)$, whereas the latter contained major amounts of mycolates with a side-chain possessing an odd number of carbon atoms. Caseobacter polymorphus contained mycolic acids of a similar size $\left(\mathrm{C}_{30}\right.$ to $\left.\mathrm{C}_{36}\right)$ to those of true corynebacteria. The mycolates of organisms assigned to the genus Rhodococcus were generally larger $\left(\mathrm{C}_{30}\right.$ to $\left.\mathrm{C}_{56}\right)$, although a clear distinction between true corynebacteria and rhodococci cannot presently be made by analysis of mycolic acids alone. Strains labelled 'Arthrobacter roseoparaffinus', Corynebacterium equi and Corynebacterium hoagii contained mycolic esters with molecular weights 'intermediate' in size between those of true corynebacteria and rhodococci. The mycolic acid data correlate well with other major trends in coryneform taxonomy and support earlier suggestions that they are of value in the classification of the group.
\end{abstract}

\section{INTRODUCTION}

Despite improvements in the classification of coryneform and related bacteria due to numerical phenetic analyses (Jones, 1978), DNA base composition determinations (Crombach, 1972; Starr et al., 1975) and cell wall analyses (Schleifer \& Kandler, 1972; Keddie \& Cure, 1977, 1978; Keddie \& Bousfield, 1980), many problems remain. Attention has increasingly turned to lipid analyses for the provision of characters for the classification of coryneform and related taxa (Goodfellow et al., 1976; Yamada et al., 1976; Collins \& Jones, 1980; Collins et al., 1977, 1979a, b, 1980; Keddie \& Cure, 1977; Minnikin et al., 1978, 1979).

Thin-layer chromatographic analysis of mycolic acids, i.e. long-chain 2-branched 3-hydroxy fatty acids, has been particularly useful in clarifying the taxonomy of the genera Corynebacterium, Mycobacterium, Nocardia and Rhodococcus (Goodfellow et al., 1976; Keddie \& Cure, 1977; Minnikin et al., 1975; Minnikin \& Goodfellow, 1980). Structural studies indicate that mycobacteria usually contain a complex mixture of mycolic acids of high

+ Present address: Department of Microbiology, National Institute for Research in Dairying, Shinfield, Reading RG2 9AT, U.K. 
molecular weight $\left(C_{60}\right.$ to $\left.C_{90}\right)$ whereas those from nocardiae and rhodococci are smaller $\left(C_{36}\right.$ to $C_{66}$ ) (Alshamaony et al., 1976a, b; Minnikin \& Goodfellow, 1980). Although the structure of mycolic acids in true corynebacteria has not been the subject of systematic analyses, preliminary studies performed to date suggest that some corynebacteria possess mycolic acids of a relatively low molecular weight $\left(C_{20}\right.$ to $\left.C_{36}\right)$ (see Minnikin et al., 1978). Furthermore, mycolic acids of similar size have been isolated from strains labelled 'Arthrobacter paraffineus' (Suzuki et al., 1969), 'Brevibacterium thiogenitalis' (Okazaki et al., 1969), Bacterionema matruchotii (Alshamaony et al., 1977) and 'Mycobacterium lacticolum var. aliphaticum' (Krasilnikov et al., 1973).

In the present study the general structures of the mycolic acids of a large number of coryneform bacteria have been investigated.

\section{METHODS}

Cultures and cultivation. Test strains (Table 1) were maintained routinely on nutrient agar (Oxoid) and Dorset egg slopes at room temperature. Strains were grown in shake culture at $30^{\circ} \mathrm{C}$ for $3 \mathrm{~d}$ in nutrient broth no. 2 (Oxoid). Cultures were checked for purity, killed by shaking with formalin, harvested by centrifugation $(10000 \mathrm{~g}$ for $10 \mathrm{~min}$ ), washed with distilled water and freeze-dried.

Whole-organism methanolysis and thin-layer chromatography. Dried organisms (50-100 mg) were degraded by acid methanolysis as described by Minnikin et al. (1975), and the hexane extracts were examined for long-chain components by thin-layer chromatography using Merck silica gel $\mathrm{H}(0.5 \mathrm{~mm}$ layers $)$ and a developing mixture of petroleum ether (b.p. $\left.60-80^{\circ} \mathrm{C}\right) /$ diethyl ether $(85: 15, \mathrm{v} / \mathrm{v})$. Mycolic acid methyl esters were isolated by preparative thin-layer chromatography on layers $(1 \mathrm{~mm})$ of Merck silica gel $\mathbf{P F}_{254+366}$ using the same developing mixture, detected by illumination with long wave ultraviolet light $(366 \mathrm{~nm})$ and eluted from the gel with chloroform.

Pyrolysis gas chromatography. Pyrolysis gas chromatography of mycolic acid methyl esters was carried out on a Perkin-Elmer F11 flame-ionization gas chromatograph fitted with stainless steel columns $(0.125 \mathrm{in}$, o.d.). Analyses were performed on $2 \mathrm{~m}$ non-polar OV-1 (2.5\% OV-1 silicone on 80-100 mesh Chromosorb G AW-DMCS; Phase Separations) and $6 \mathrm{~m}$ Silar 10C (10\% Silar 10C on 100-120 mesh Gas-Chrom Q; Applied Science Laboratories) columns using nitrogen as carrier gas at isothermal oven temperatures of $180^{\circ} \mathrm{C}$ and $210^{\circ} \mathrm{C}$, respectively. Components in the chromatograms were identified by comparing their retention times with those of authentic long-chain esters and aldehydes.

Mass spectrometry. Mass spectra of mycolic esters were taken on an AEI MS9 instrument using a direct insertion probe, an ionizing voltage of $70 \mathrm{eV}$ and a temperature of $160-200^{\circ} \mathrm{C}$.

Table 1. Mycolic acid-containing test strains and their sources

$\begin{array}{ll}\text { Name as received } & \text { Nof } \\ \text { strains }\end{array}$

'Arthrobacter albidus'

'A. hydrocarboglutamicus'

'A . paraffineus'

A. picolinophilus

'A. roseoparaffinus'

A. variabilis

Brevibacterium ammoniagenes

'B. butanicum'

'B. chang-fua'

$B$. divaricatum

'B. flavum'

'B. glutamigenes'

'B. healii'

'B. immariophilum'

'B. ketoglutamicum'

'B. lactofermentum'

'B. paraffinolyticum'

'B. roseum'

'B. saccharolyticum'

B. stationis
No. of
strains

1

1

1

1

1

1

1

1

1

1

1

1

I

1

1

1

I

1
Strain designation(s)/source + .
D6 (NCIB 10266)
C795 (ATCC 15583)
C228 (NCIB 10699)
C905 (ATCC 27854)
C 112 (NCIB 10700)
*D2 (NCIB 9455)
C80 (NCIB 8143)
C790 (ATCC 21196)
C794 (ATCC 14017)
D3 (NCIB 9379)
C81 (NCIB 9565)
C 900 (ATCC 13747)
C903 (ATCC 15527)
${ }^{*} \mathrm{C} 123$ (NCIB 9544)
C260 (DSM 20165)
C 124 (NCIB 9567)
C 113 (NCIB 11160)
C82 (NCIB 9564)
C 127 (NCIB 9543)
*C41 (ATCC 14403) 
Table 1. (cont.)

Name as received $t$

'B. sterolicum'
'B. taipei'
Caseobacter polymorphus

'Corynebacterium acetoacidophilum'

'C. alkanum'

C. bovis

C. callunae

C. diphtheriae

C. equi

C. fascians

'C. flavidum'

C. glutamicum

'C. herculis'

C. hoagii

'C. hydrocarboclastus'

C. kutscheri

C. lilium

'C. melassecola'

'C. minutissimum'

'C. mycetoides'

C. pseudodiphtheriticum

C. pseudotuberculosis

C. renale

'C. rubrum'

'C. segmentosum'

'C. ulcerans'

C. xerosis

Corynebacterium sp.

'Microbacterium ammoniaphilum'

'Microbacterium flavum'

'Mycobacterium lacticolum'

'Mycobacterium rubrum subsp. propanicum'
No. of strains

Strain designation(s)/source +

C188 (NCIB 11161)

C796 (ATCC 13744)

*C357 (NCDO 2097); C358 (NCDO 2099); C359

(NCDO 2101): C360 (NCDO 2102)

C129 (NCIB 9661)

C901 (ATCC 21194)

*C12 (NCTC 3224); C95 (NIRD 1689); C 97 (NIRD

1928); C98 to C 103 (J. Schreeve: DB223/75,

DB 132/75, DB2 10/75, 30/75, DB94/75, 120B)

*C130 (NCIB 10338)

C 13 (NCTC 3985); C 14 (NCTC 3987); C 32 (NCTC

3984); C66 (NCTC 3529); C67 (NCTC 10681)

*C7 (NCTC 1621)

*C1 (ATCC 12974): C 104 (NCPPB 1488): Nl46 (M.

Turner: 39$)$

C35 (NCTC 764)

D7 (NCIB 10025)

${ }^{*}$ C 85 (NCIB 9694)

C24 (NCTC 10673)

*D8, D9 (K. Komagata: AJ 1386, AJ 1379)

C20 (NCTC 949): C59 (NCTC 1386); C60 (NCTC $3655)$

C 133 (NCIB 10337)

C136 (NCIB 10336)

*D24 (NCTC 10288); D24B (NCTC 10285)

C63 (NCTC 9864)

C19 (NCTC 231); C 37 (D. Jones: C 10)

C 15 (NCTC 3450); C 214 (NCTC 4655); C 215 (NCTC

4681): C216 (NCTC 4691); C 142. C 150 to C 156

(H. R. Carne: Ov 133, Ov 1134, Ov 1139, Cap 16.

Cap.16-F302-4; Cap.16-F302-35, E107. E1144); H5,

H7 (P. Maximescu: 992. 993)

4

C 17 (NCTC 7448); H1, H2, H4 (R. Yanagawa, 43, 45.

42)

${ }^{*}$ C $190($ NCIB 9433)

C64 (NCTC 934)

C18 (NCTC 7910); C170, C 172, C 174, C176. C 178, C179, C180 (H. R. Carne: JW2, JW7, JW33, JW40. PM39C, PM298G, PM319C); H6. H8 (P. Maximescu: 896. 985)

3

C 27 (NCTC 7238): C 137 (NCIB 9956); C 33 (NCTC 9755)

4 D11, D16. D 17, D 18 (I. J. Bousfield: marine isolates SN66. SN123, SN 149, SN130)

C 139 (NCIB 10335)

D4 (NCIB 8707)

C237 (NCIB 9740)

C239 (NCIB 9741)

* Type strain.

+ Taxa which are not included in the Approved Lists of Bacterial Names (Skerman et al.. 1980) are shown in quotation marks.

‡ATCC, American Type Culture Collection, Rockville, Maryland, U.S.A.; DSM, Deutsche Sammlung von Microorganismen, Teilsammlung, 61 Darmstadt, West Germany; NCIB, National Collection of Industrial Bacteria, Aberdeen, U.K.; NCPPB, National Collection of Plant Pathogenic Bacteria, Harpenden, Herts. U.K.; NCTC, National Collection of Type Cultures. London. U.K.; NCDO. National Collection of Dairy Organisms. Shinfield. Reading. U.K.; NIRD, National Institute for Research in Dairying, Shinfield, Reading, U.K.; I. J. Bousfield, Torry Research Station, Aberdeen, U.K.: H. R. Carne, University of Cambridge, U.K.; D. Jones, Department of Microbiology, University of Leicester, U.K.; K. Komagata, Ajinomoto Co., Kawasaki, Japan; P. Maximescu, Dr I. Cantacuzino Institute, Bucharest, Rumania; J. Shreeve, Bacteriology Department, Central Veterinary Laboratory. New Haw. Weybridge, U.K.; M. Turner. University of Nottingham. U.K.; R. Yanagawa, Hokkaido University, Sapporo, Japan. C, D, H and $\mathrm{N}$ are laboratory numbers. 


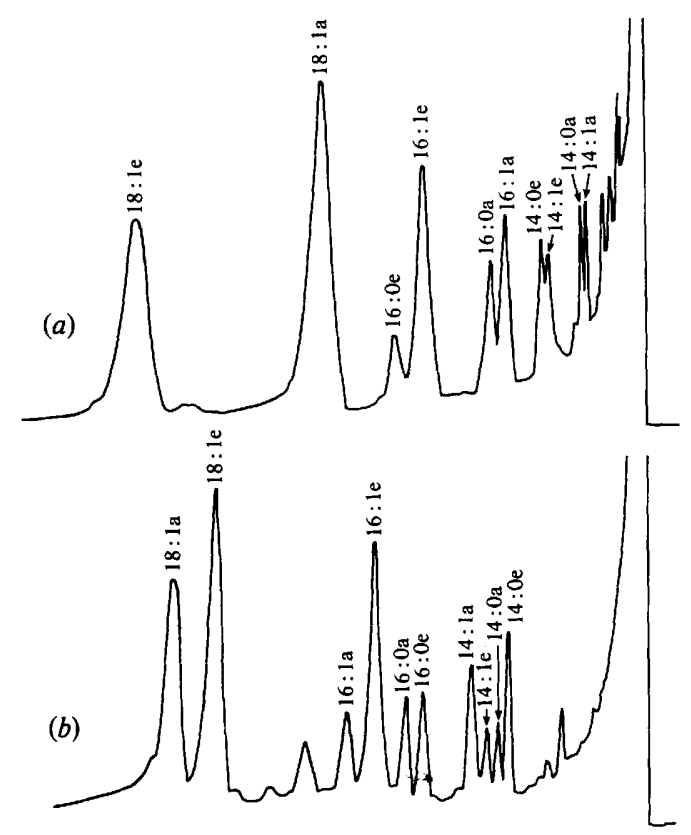

Fig. 1. Pyrolysis gas chromatographic analysis of mycolic acid methyl esters of Corynebacterium xerosis C33 on OV-1 (profile $a$ ) and Silar 10C (profile $b$ ). On each peak, the first number indicates the number of carbon atoms, the second indicates the number of double bonds and the final letter indicates whether it is an aldehyde (a) or ester (e).

\section{RESULTSAND DISCUSSION}

Thin-layer chromatographic analysis of the whole-organism methanolysates revealed the presence of mycolic acid methyl esters $\left(R_{F} 0.2\right.$ to 0.5$)$ in all of the test strains (Table 1 ). Pyrolysis gas chromatography of the mycolic acid methyl esters from Corynebacterium xerosis C33 was performed in order to clarify the interpretation of the mass spectra of the mycolic esters under consideration. The analyses were performed on both polar and non-polar stationary phases: the results are shown in Fig. 1. Pyrolysis gas chromatography of mycolic esters yields mixtures of long-chain esters and aldehydes (Etémadi, 1967; Lechevalier et al., 1973), and from the mycolates of C. xerosis C33 complex mixtures of mainly monounsaturated components were observed (Fig. 1).

Methyl esters of mycolic acids fragment on mass spectrometry in several competing pathways depending on their overall size and structural features (Etémadi, 1967; Maurice $e t$ al., 1971; Alshamaony et al., 1976a, b; Minnikin \& Goodfellow, 1976, 1980; Goodfellow et al., 1978) as summarized in Fig. 2. The highest peaks in the mass spectra of methyl mycolates correspond to anhydromycolates formed by the elimination of the elements of water from the parent molecule. Cleavage according to $a$ and $a^{\prime}$ (Fig. 2) involves net transfer of the hydroxyl hydrogen atom to give long-chain aldehydes (meroaldehydes) and esters. Unsaturated esters produced by cleavage $a$ do not give prominent peaks but readily lose the elements of methanol to give characteristic fragments X (Fig. 2; Goodfellow et al., 1978). Fragments Y due to cleavage $b$ complement those arising from $a$ and assist in determining the overall size of the side-chain $\mathrm{R}_{1}$ (Fig. 2).

In the present study, peaks at $m / e 158,186,214,242,256,270,284$ and 298 correspond to saturated esters (Fig. 2; cleavage $a$ ) and fragments at $m / e$ 187, 215, 243, 271, 285, 299, 313 and 327 (Fig. 2; cleavage $b$ ) confirm the presence of side-chains $\mathrm{R}_{1}$ (Fig. 2) having the overall elemental composition $\mathrm{C}_{6} \mathrm{H}_{13}, \mathrm{C}_{8} \mathrm{H}_{17}, \mathrm{C}_{10} \mathrm{H}_{21}, \mathrm{C}_{12} \mathrm{H}_{25}, \mathrm{C}_{13} \mathrm{H}_{27}, \mathrm{C}_{14} \mathrm{H}_{29}, \mathrm{C}_{15} \mathrm{H}_{31}$ and 


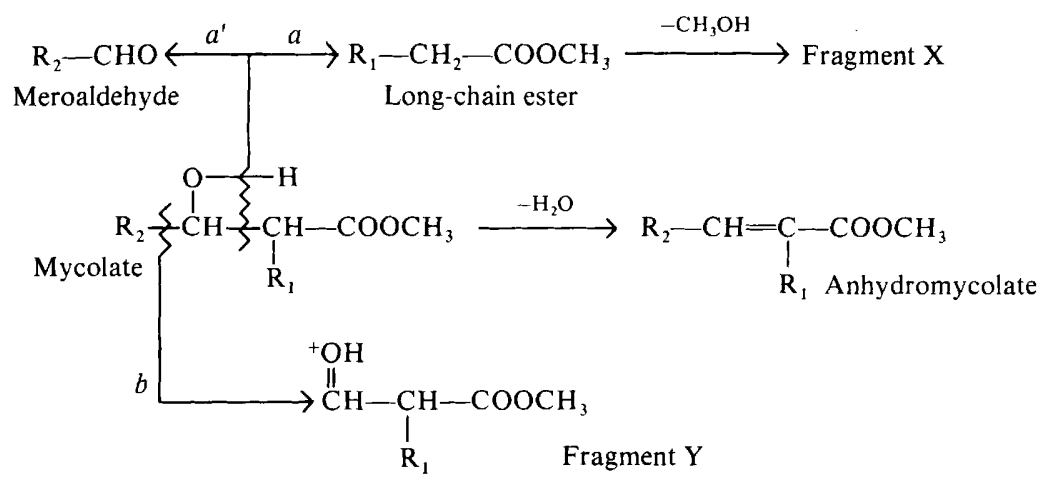

Fig. 2. Mass spectral fragmentation pathways for mycolic acid methyl esters.

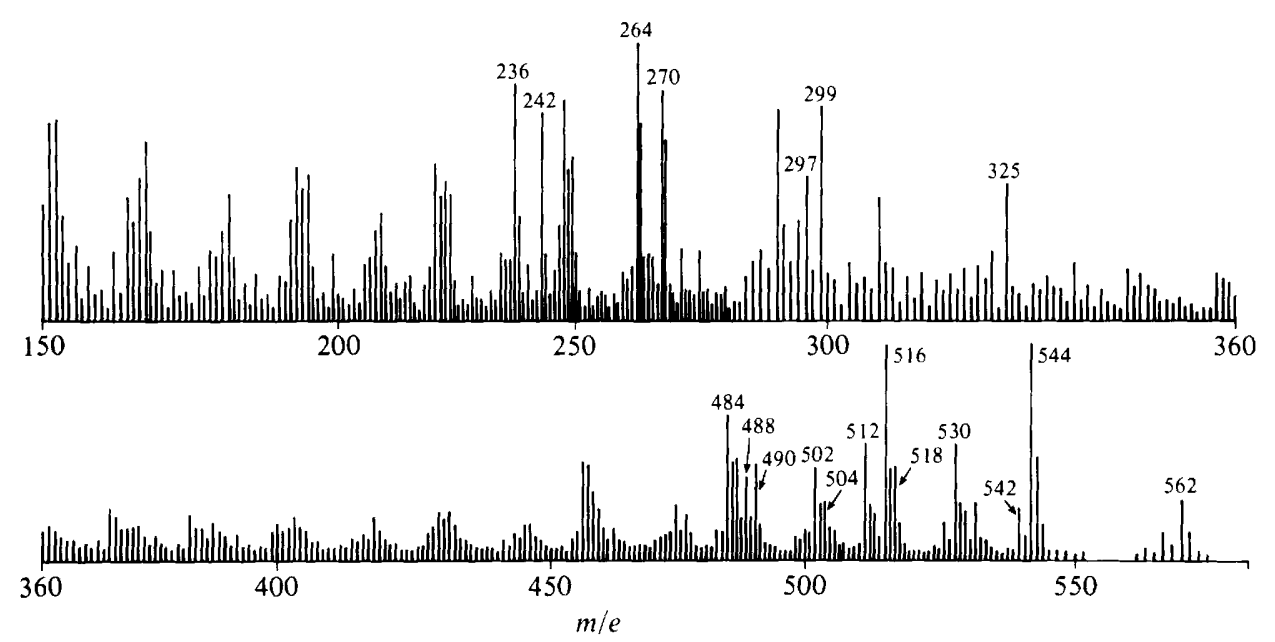

Fig. 3. Partial mass spectrum of mycolic acid methyl esters of Corynebacterium xerosis C33.

$\mathrm{C}_{16} \mathrm{H}_{33}$, respectively. The presence of side-chains $\mathrm{C}_{14} \mathrm{H}_{27}$ and $\mathrm{C}_{16} \mathrm{H}_{31}$, containing one double bond, was shown by the presence of small peaks at $m / e$ 268/297 and 296/325 and larger fragments at $m / e 236$ and 264 formed by elimination of the elements of methanol from the parent ester (Fig. 2). The intensities of the last peaks ( $\mathrm{X}^{+}$, Fig. 2 ), however, are variable due to the presence of other competing reactions and do not accurately reflect the proportions of monounsaturated side-chains $\left(R_{1}\right)$ in the parent mycolates.

The variety of competing pathways (Fig. 2) and the similarity of the size of the fragments occurring in the mass spectra of the mycolic esters under study make it difficult to propose accurate structures based on mass spectral analysis alone. In the partial mass spectrum of the mycolic acid methyl esters of C. xerosis C33 (Fig. 3), for example, prominent peaks at $m / e$ 516 and 544 are due to the main components of anhydromycolates (Fig. 2) corresponding to diunsaturated $\mathrm{C}_{34}$ and $\mathrm{C}_{36}$ parent mycolic acids, respectively. Smaller peaks can be assigned to the minor series of anhydromycolates (Fig. 3) and other peaks, m/e 484 and 512 for example, are due to loss of the elements of methanol from the major anhydromycolates.

The complex array of peaks in the region m/e 200-350 of the mass spectrum of the mycolates from C.xerosis C33 (Fig. 3) is mainly due to fragments including the side-chain $\mathrm{R}_{1}$ (Fig. 2). Peaks at $m / e 236$ and 264 (Fig. 3) do correspond in size, as noted previously (Alshamaony et al., 1977), to diunsaturated aldehydes, but on pyrolysis gas chromatography no such aldehydes were detected. Monounsaturated esters lose the elements of methanol 


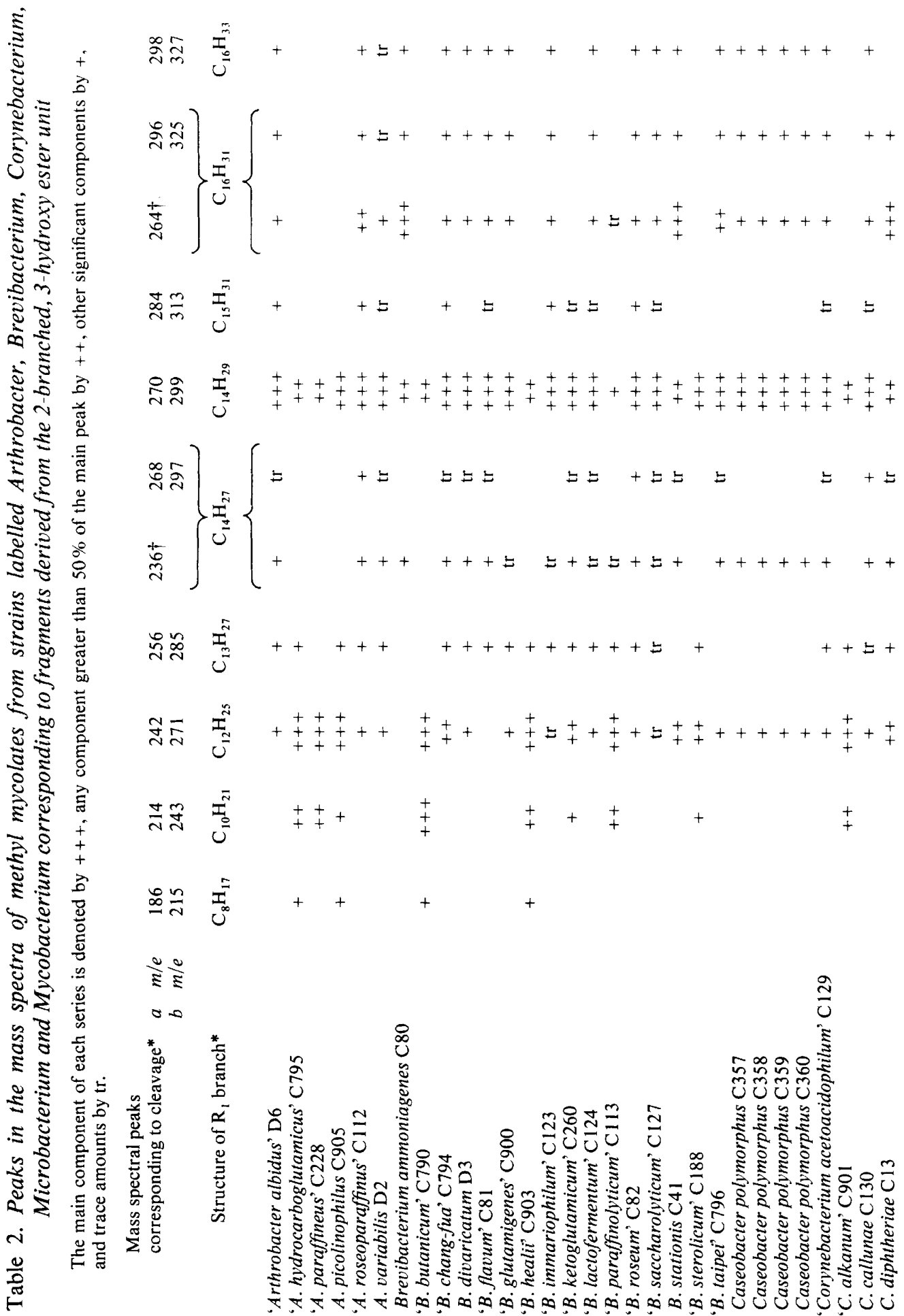




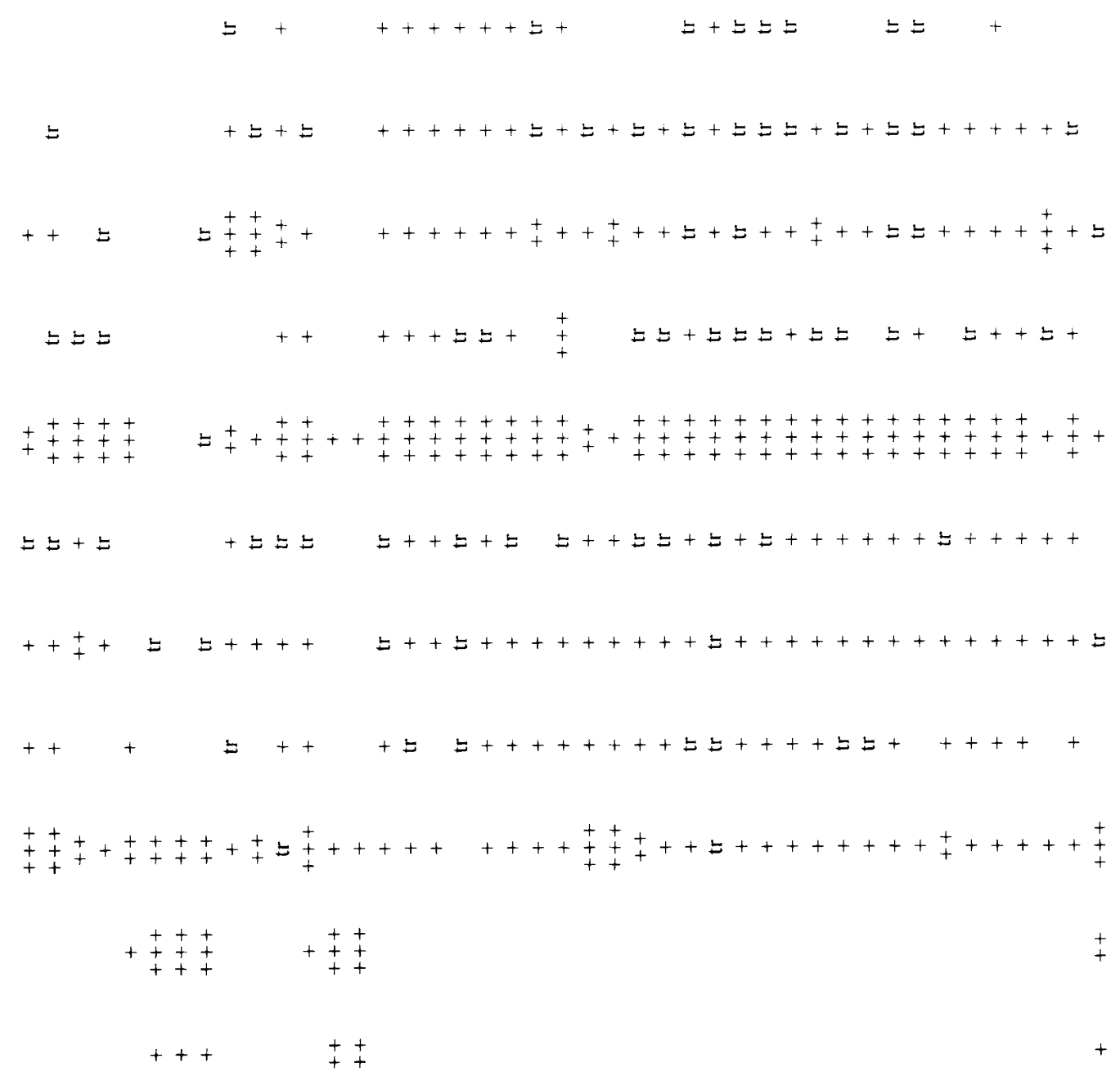

ㅇํำ

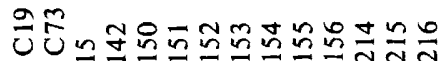

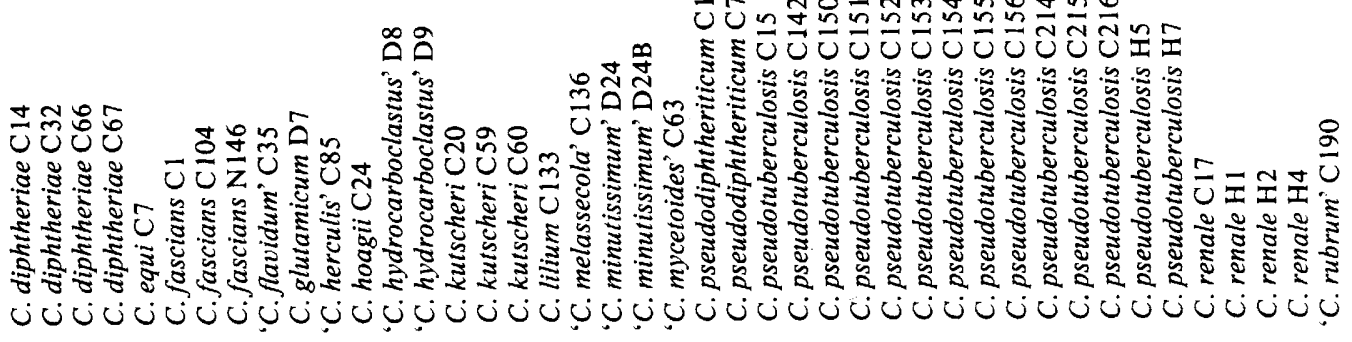




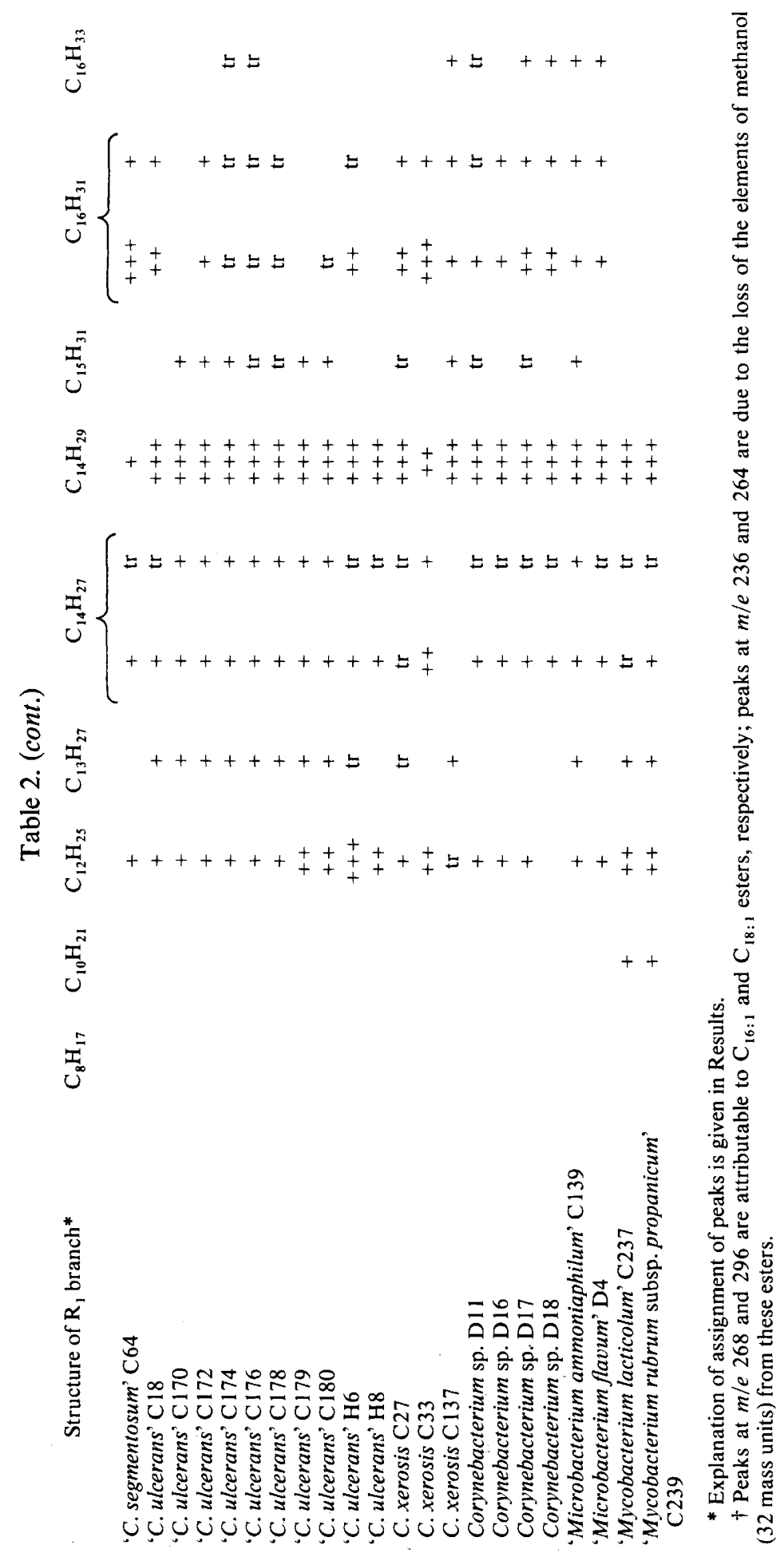


Table 3. Peaks in the mass spectra of methyl mycolates from Corynebacterium bovis strains corresponding to anhydromycolates

The main component of each series is denoted by +++ , any component greater than $50 \%$ of the main peak by ++ , and all other significant components by + .

\begin{tabular}{|c|c|c|c|c|c|c|c|c|c|c|c|}
\hline \multirow{2}{*}{$\begin{array}{l}\text { No. of carbons } \\
\text { in parent } \\
\text { mycolic acid }\end{array}$} & \multirow[b]{2}{*}{$m / e$} & \multirow{2}{*}{$\begin{array}{l}\text { No. of } \\
\text { double } \\
\text { bonds }\end{array}$} & \multicolumn{9}{|c|}{ C. bovis } \\
\hline & & & $\mathrm{Cl} 2$ & C95 & C97 & C98 & C99 & $\mathrm{C} 100$ & C 101 & $\mathrm{C} 102$ & C 103 \\
\hline$C_{22}$ & 350 & 1 & & & & & + & + & & & \\
\hline $\mathrm{C}_{23}$ & 364 & 1 & & & + & & ++ & + & & & \\
\hline $\mathrm{C}_{24}$ & $\begin{array}{l}376 \\
378\end{array}$ & $\begin{array}{l}2 \\
1\end{array}$ & $\begin{array}{l}+ \\
+\end{array}$ & ++ & ++ & + & +++ & $\begin{array}{c}++ \\
+++\end{array}$ & + & + & + \\
\hline$C_{25}$ & $\begin{array}{l}390 \\
392\end{array}$ & $\begin{array}{l}2 \\
1\end{array}$ & + & $\begin{array}{l}+ \\
+\end{array}$ & + & $\begin{array}{l}+ \\
+\end{array}$ & $\begin{array}{c}+ \\
++\end{array}$ & $\begin{array}{c}+ \\
++\end{array}$ & $\begin{array}{l}+ \\
+\end{array}$ & + & $\begin{array}{l}+ \\
+\end{array}$ \\
\hline $\mathrm{C}_{26}$ & $\begin{array}{l}404 \\
406\end{array}$ & $\begin{array}{l}2 \\
1\end{array}$ & + & ++ & $\begin{array}{c}+ \\
++\end{array}$ & ++ & $\begin{array}{c}+ \\
++\end{array}$ & $\begin{array}{c}+ \\
++\end{array}$ & + & ++ & ++ \\
\hline$C_{27}$ & $\begin{array}{l}418 \\
420\end{array}$ & $\begin{array}{l}2 \\
1\end{array}$ & $\begin{array}{c}+ \\
++\end{array}$ & $\begin{array}{l}++ \\
++\end{array}$ & $\begin{array}{c}+ \\
++\end{array}$ & $\begin{array}{c}+ \\
++\end{array}$ & $\begin{array}{l}+ \\
+\end{array}$ & $\begin{array}{c}+ \\
++\end{array}$ & $\begin{array}{c}+ \\
++\end{array}$ & $\begin{array}{l}++ \\
++\end{array}$ & $\begin{array}{c}+ \\
++\end{array}$ \\
\hline $\mathrm{C}_{28}$ & $\begin{array}{l}432 \\
434\end{array}$ & $\begin{array}{l}2 \\
1\end{array}$ & $\begin{array}{c}+ \\
+++\end{array}$ & $\begin{array}{c}++ \\
+++\end{array}$ & $\begin{array}{c}++ \\
+++\end{array}$ & $\begin{array}{c}++ \\
+++\end{array}$ & $\begin{array}{c}+ \\
++\end{array}$ & $\begin{array}{c}+ \\
++\end{array}$ & $\begin{array}{c}+ \\
+++\end{array}$ & $\begin{array}{c}++ \\
+++\end{array}$ & $\begin{array}{c}+ \\
++\end{array}$ \\
\hline $\mathrm{C}_{29}$ & $\begin{array}{l}446 \\
448 \\
450\end{array}$ & $\begin{array}{l}2 \\
1 \\
0\end{array}$ & $\begin{array}{l}+ \\
+\end{array}$ & $\begin{array}{l}+ \\
+ \\
+\end{array}$ & $\begin{array}{l}+ \\
+\end{array}$ & $\begin{array}{l}+ \\
+\end{array}$ & $\begin{array}{l}+ \\
+\end{array}$ & $\begin{array}{l}+ \\
+ \\
+\end{array}$ & $\begin{array}{l}+ \\
+\end{array}$ & $\begin{array}{l}+ \\
+\end{array}$ & $\begin{array}{l}+ \\
+\end{array}$ \\
\hline$C_{30}$ & $\begin{array}{l}460 \\
462\end{array}$ & $\begin{array}{l}2 \\
1\end{array}$ & $\begin{array}{l}+ \\
+\end{array}$ & + & + & $\begin{array}{l}+ \\
+\end{array}$ & $\begin{array}{l}+ \\
+\end{array}$ & $\begin{array}{l}+ \\
+\end{array}$ & $\begin{array}{l}+ \\
+\end{array}$ & $\begin{array}{l}+ \\
+\end{array}$ & $\begin{array}{l}+ \\
+\end{array}$ \\
\hline$C_{31}$ & $\begin{array}{l}474 \\
476\end{array}$ & $\begin{array}{l}2 \\
1\end{array}$ & $\begin{array}{l}+ \\
+\end{array}$ & $\begin{array}{l}+ \\
+\end{array}$ & $\begin{array}{l}+ \\
+\end{array}$ & $\begin{array}{l}+ \\
+\end{array}$ & & & $\begin{array}{l}+ \\
+\end{array}$ & $\begin{array}{l}+ \\
+\end{array}$ & $\begin{array}{l}+ \\
+\end{array}$ \\
\hline $\mathrm{C}_{32}$ & $\begin{array}{l}488 \\
490\end{array}$ & $\begin{array}{l}2 \\
1\end{array}$ & $\begin{array}{l}+ \\
+\end{array}$ & + & $\begin{array}{l}+ \\
+\end{array}$ & $\begin{array}{l}+ \\
+\end{array}$ & & & & $\begin{array}{l}+ \\
+\end{array}$ & $\begin{array}{l}+ \\
+\end{array}$ \\
\hline
\end{tabular}

much more readily than saturated esters (Campbell \& Naworal, 1969; Goodfellow et al., 1978) and the peaks at $m / e 236$ and 264 must be such products formed from monounsaturated $\mathrm{C}_{16}$ and $\mathrm{C}_{18}$ esters. Peaks in the mass spectra attributable to aldehydes were not clearly identifiable for the mycolates under study. The detection of aldehyde fragments was also unreliable in the spectra of mycolates from nocardiae and rhodococci (Alshamaony et al., $1976 a, b$ ), but for mycobacterial mycolates the peaks due to aldehydes were consistently recorded (Etémadi, 1967). The series of peaks corresponding to anhydromycolates were, however, very reliable in appearance. Interpretation of the mass spectra of the mycolic acid methyl esters from the test organisms, bearing in mind the complexities demonstrated for $C$. xerosis $\mathrm{C} 33$, enabled us to determine the distribution of the side-chains $\mathrm{R}_{1}$ (Table 2) and the anhydromycolate compositions (Tables 3 to 6).

The mycolic acids from Corynebacterium bovis strains were particularly distinctive (Table 3) having a carbon range of $\mathrm{C}_{22}$ to $\mathrm{C}_{32}$ and side-chains $\mathrm{R}_{1}$ of the composition $\mathrm{C}_{6} \mathrm{H}_{13}$ and $\mathrm{C}_{8} \mathrm{H}_{17}$ (major component). The presence of such small parent acids and side-chains $\mathrm{R}_{1}$ distinguishes $C$. bovis from all other corynebacteria examined.

Corynebacterium diphtheriae strains contained mycolic acids with carbon ranges between $\mathrm{C}_{28}$ and $\mathrm{C}_{36}$, consisting of saturated, mono- and diunsaturated components (Table 4). These mycolates possessed predominantly saturated $C_{12}$ and $C_{14}$ side-chains $R_{1}$, although in one strain (NCTC 3985) major amounts of a monounsaturated $\mathrm{C}_{16}$ side-chain were detected (Table 2). These results are in agreement with previous reports of mycolic acids with carbon ranges of $C_{28}$ to $C_{32}$ (Senn et al., 1967; Beaman et al., 1974) and $C_{26}$ to $C_{34}$ (Alshamaony et al., 1977) from $C$. diphtheriae strains.

The animal pathogens $C$. kutscheri, 'C. minutissimum', $C$. pseudotuberculosis, $C$. renale and ' $C$. ulcerans' all contained parent mycolic acids with carbon ranges between $\mathrm{C}_{26}$ and $\mathrm{C}_{36}$; 


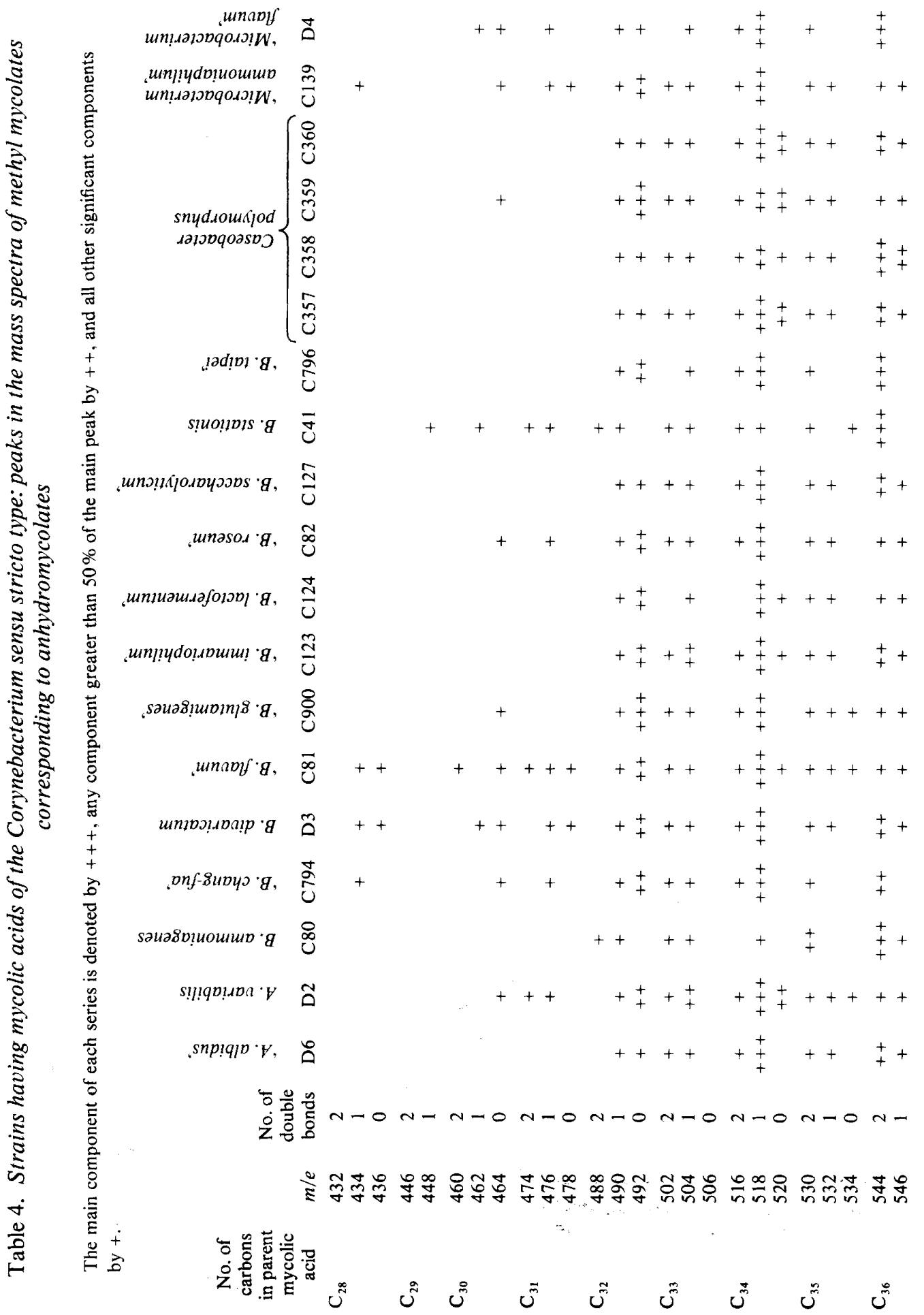


sарторахи: ว,

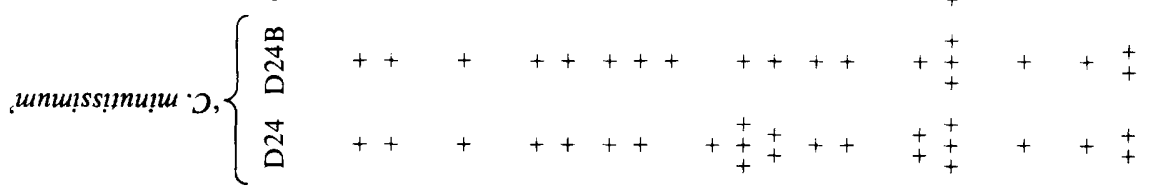

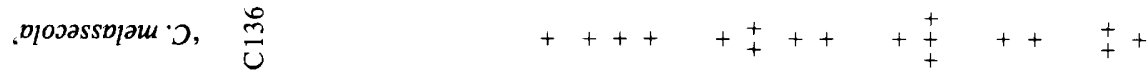

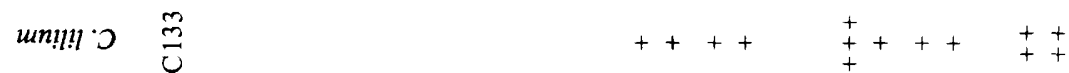

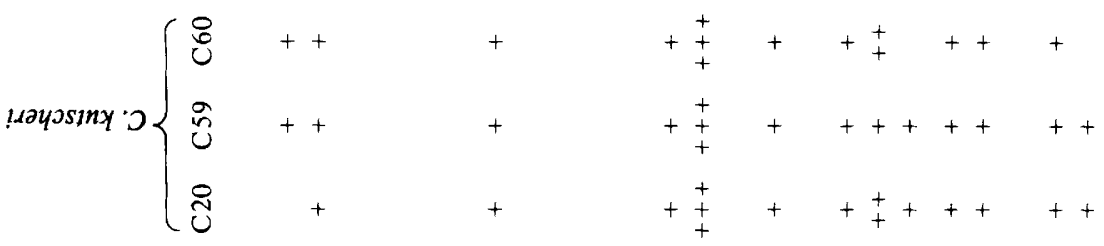

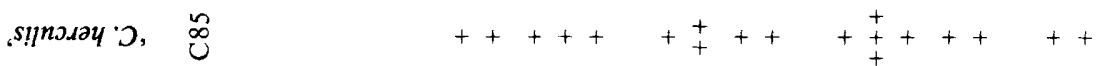

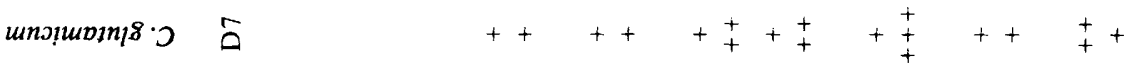

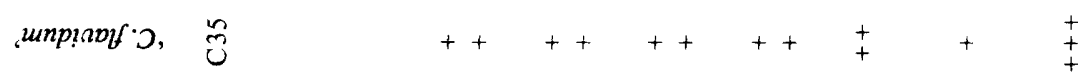

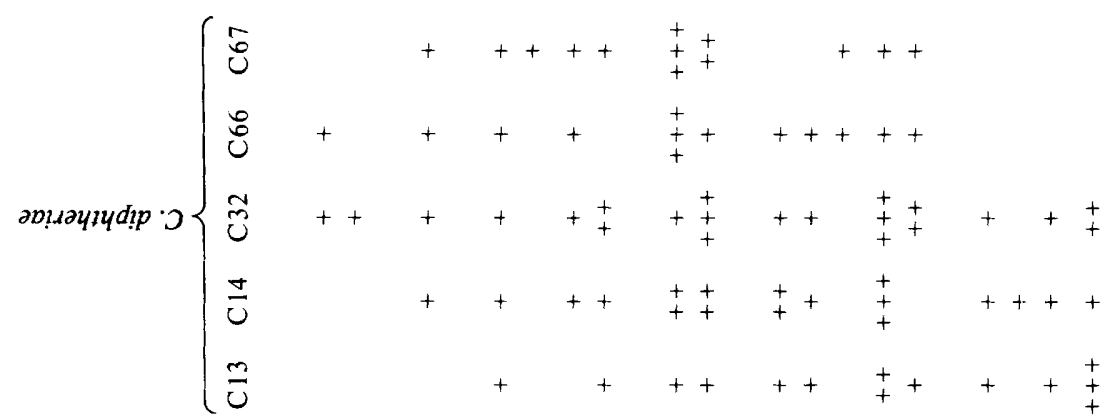

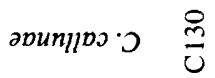

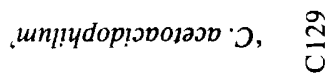

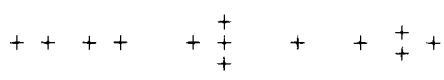
$++++\frac{+}{+}++\frac{+}{+}+$

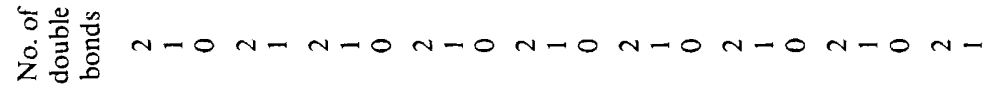

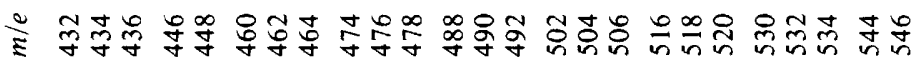

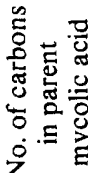

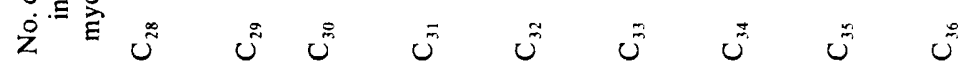




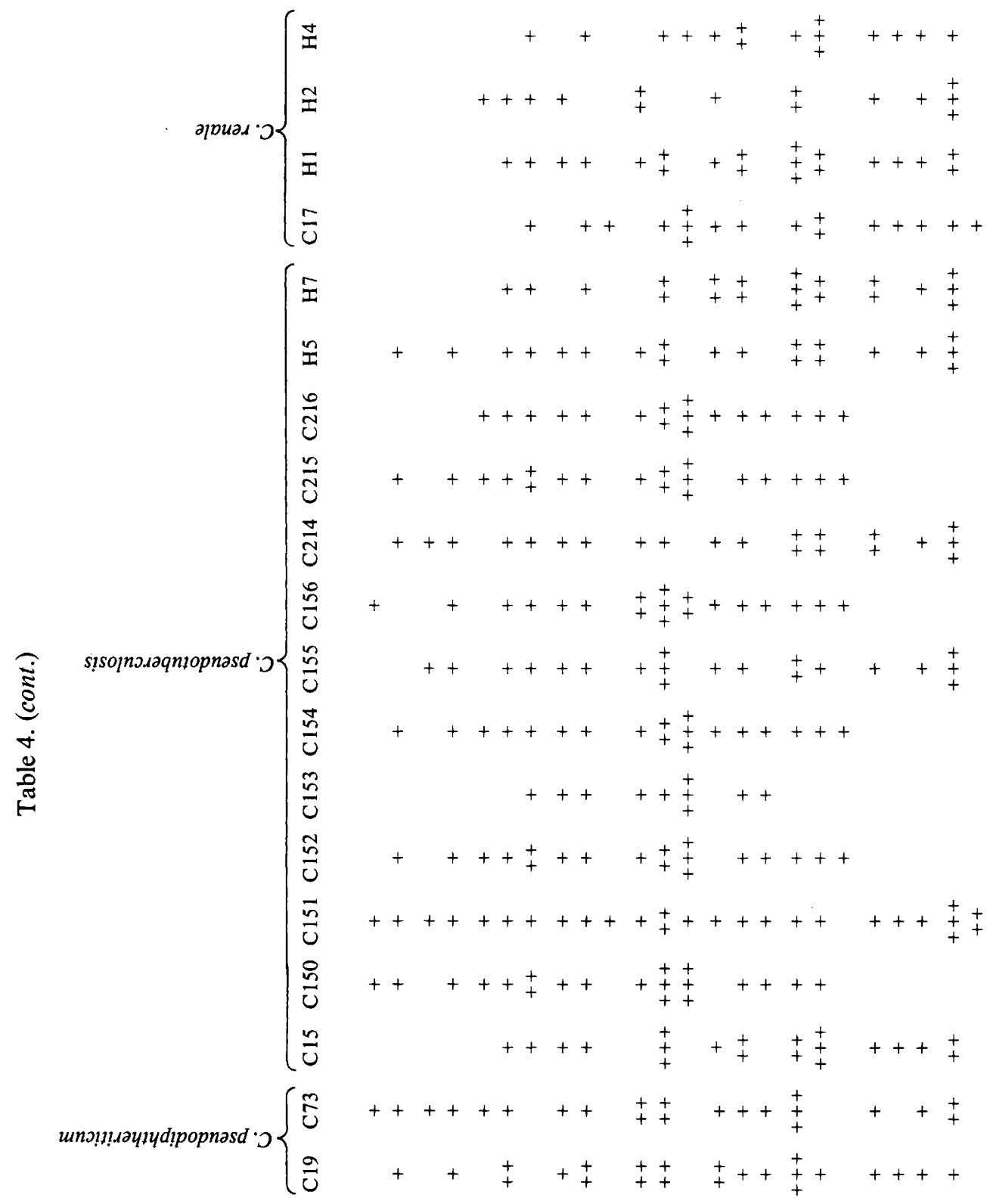

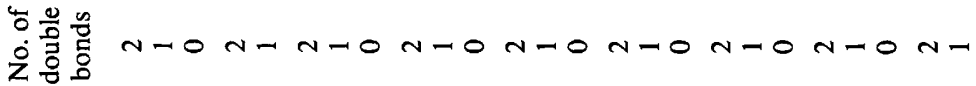

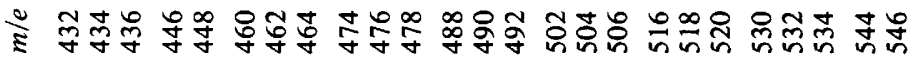

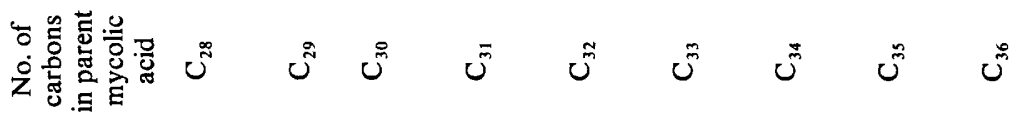




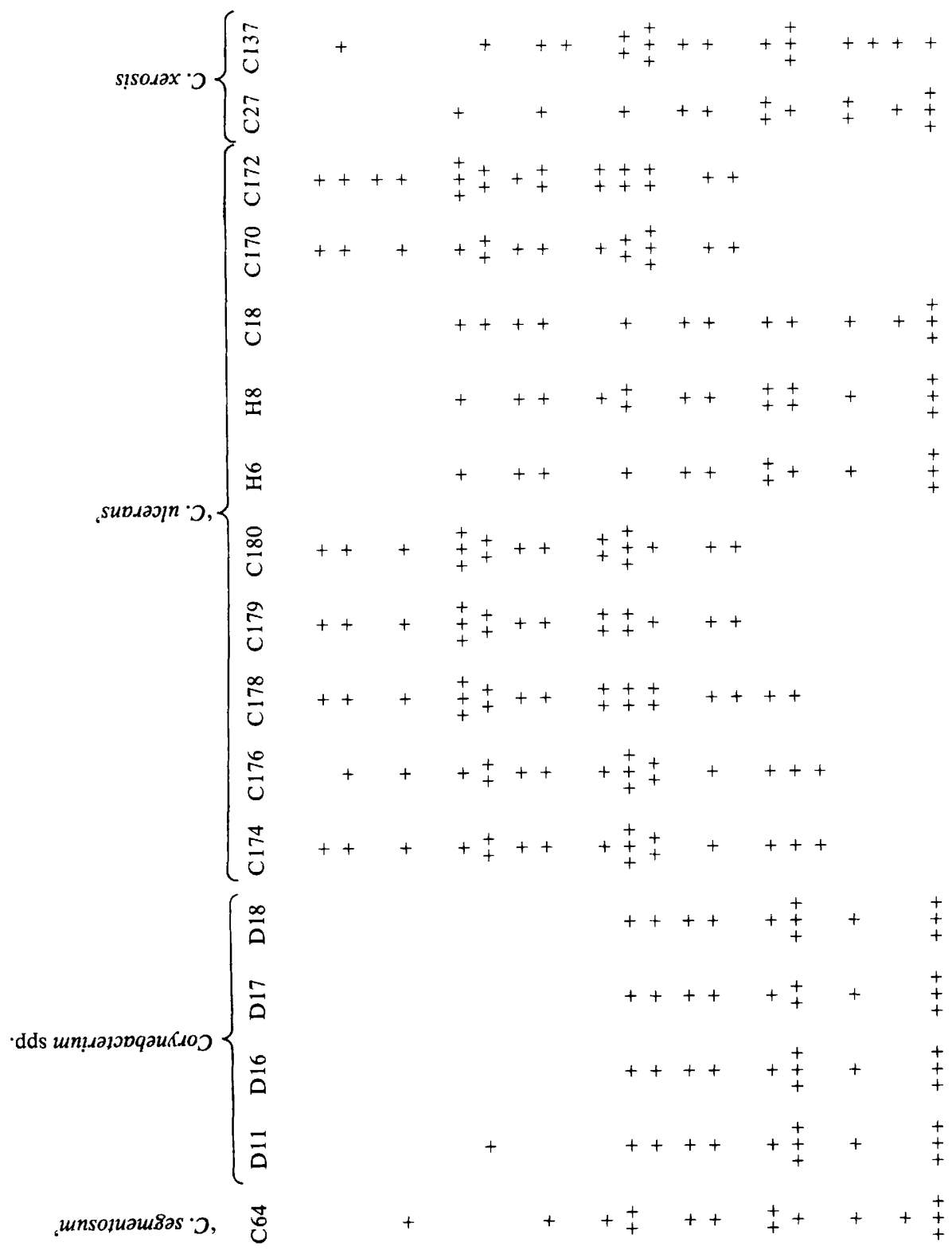

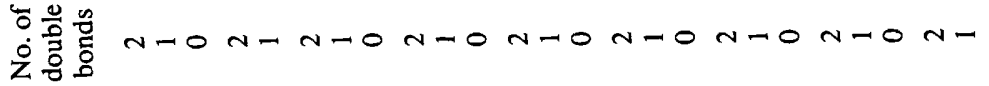

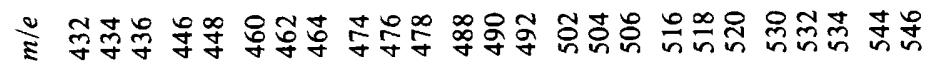

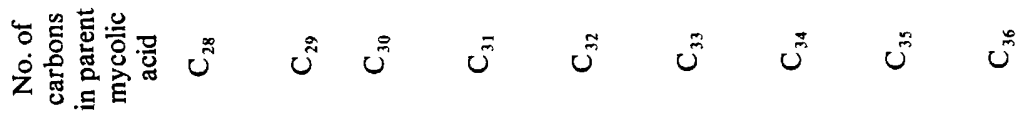




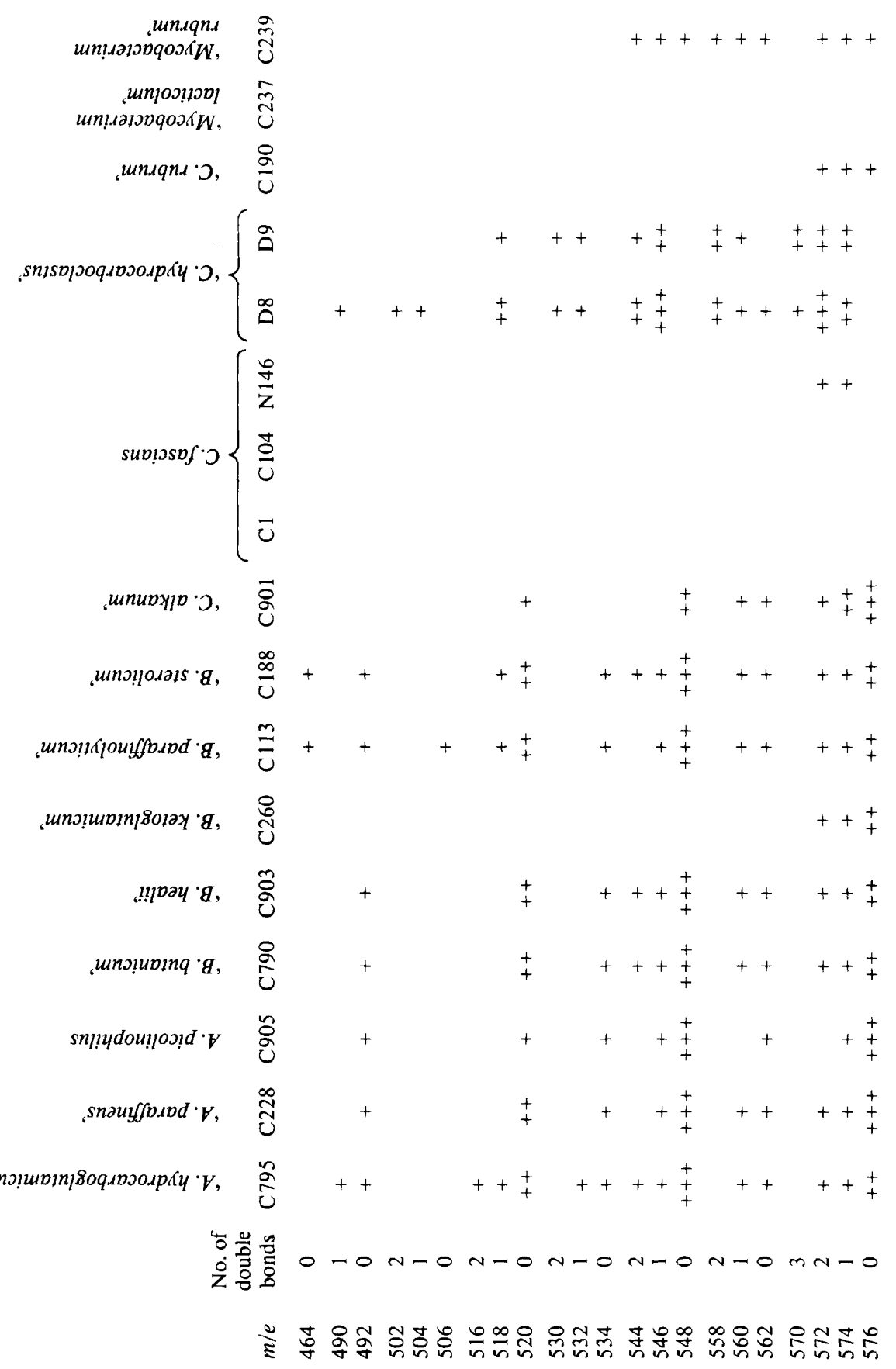

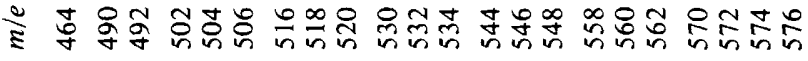

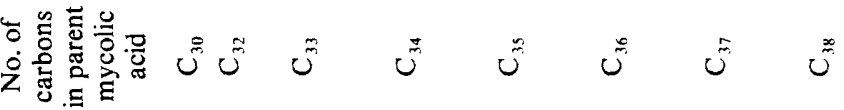




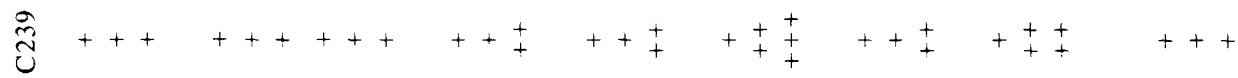

$$
\begin{aligned}
& \text { こิ } \quad+++++++++++++++++++
\end{aligned}
$$

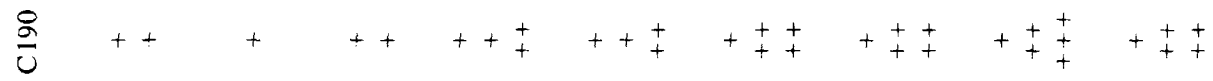

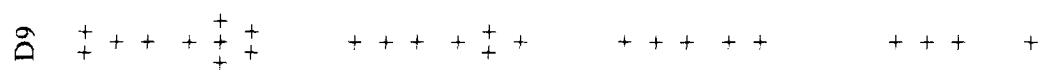

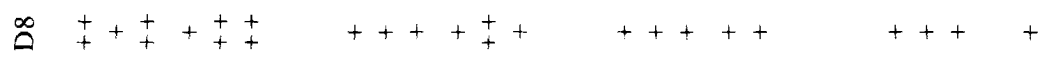

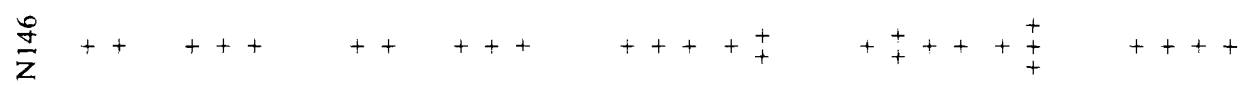

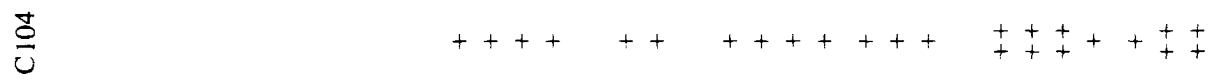

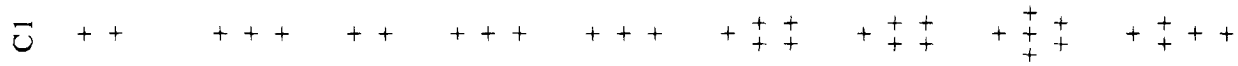

$$
\begin{aligned}
& \overrightarrow{\mathrm{S}}+++\underset{+}{+}+++++++++++++
\end{aligned}
$$

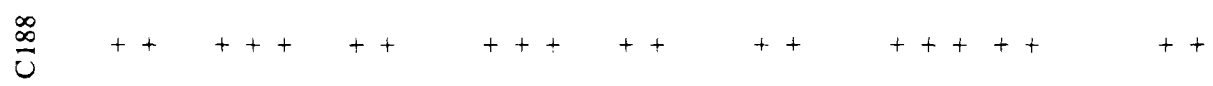

$$
\begin{aligned}
& \stackrel{m}{\Xi}+++++++++ \\
& \text { ठ } \\
& \text { 总 }+++++++++++++++
\end{aligned}
$$

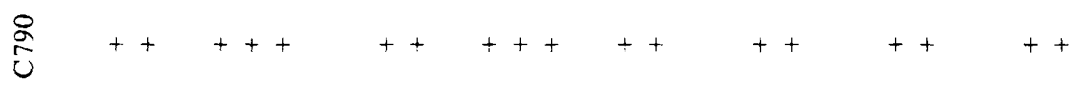

$$
\begin{aligned}
& \text { 多 }+++++++++\quad+++++++
\end{aligned}
$$

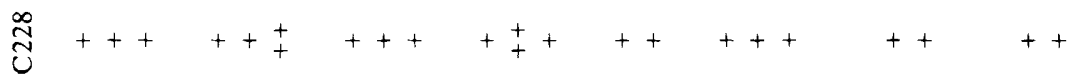

$$
\begin{aligned}
& \underset{2}{\tilde{0}}++++++++++++++++
\end{aligned}
$$

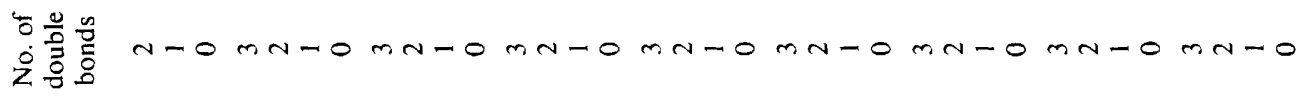

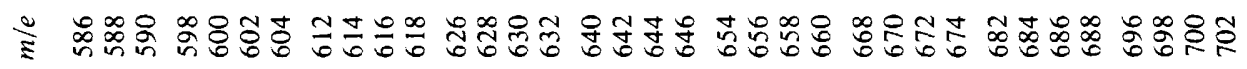

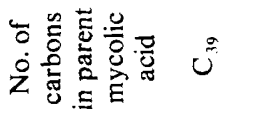
$u^{*} \quad U^{*} \quad U^{*}$ $\ddot{\tilde{u}}$ 过 ن் U 


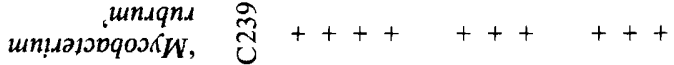

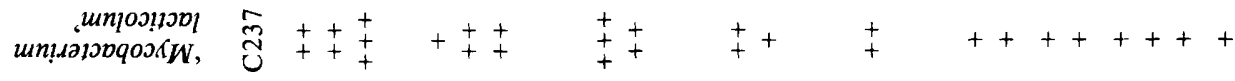

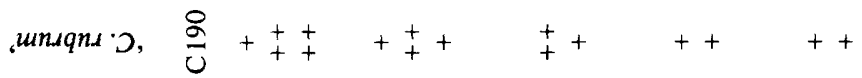

$$
\begin{aligned}
& \text { snısplooq.ıpoup }\left\{y \cdot 0,\left\{\begin{array}{l}
\stackrel{\circ}{\circ} \\
\stackrel{0}{\circ}
\end{array}\right.\right.
\end{aligned}
$$

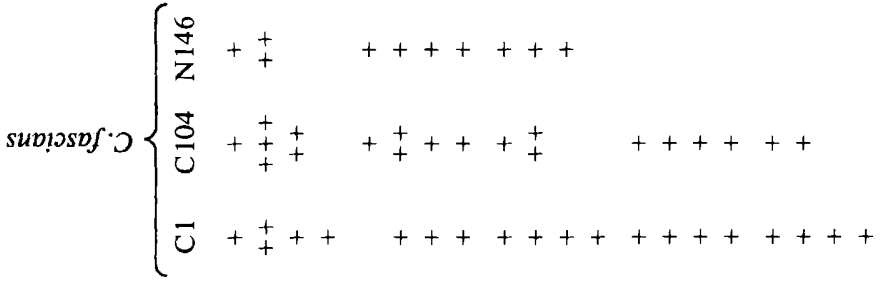

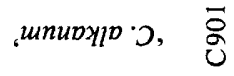

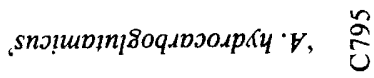

$$
\begin{aligned}
& \text { ¿̇ }
\end{aligned}
$$

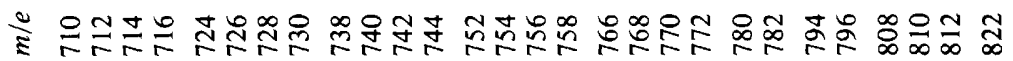


Table 6. Strains having mycolic acids intermediate between Corynebacterium sensu stricto and Rhodococcus types: peaks in the mass spectra of methyl mycolates corresponding to anhydromycolates

The main component of each series is denoted by +++ , any component greater than $50 \%$ of the main peak by ++ , and all other significant components by + .

$\begin{array}{cc}\begin{array}{c}\text { No. of carbons } \\ \text { in parent } \\ \text { mycolic acid }\end{array} & \\ \mathrm{C}_{30} & \\ \mathrm{C}_{31} & 464 \\ & 476 \\ \mathrm{C}_{32} & 478 \\ & 488 \\ & 490 \\ \mathrm{C}_{33} & 492 \\ & 502 \\ & 504 \\ \mathrm{C}_{34} & 506 \\ & 516 \\ & 518 \\ \mathrm{C}_{35} & 520 \\ & 530 \\ \mathrm{C}_{36} & 532 \\ & 534 \\ & 544 \\ \mathrm{C}_{37} & 546 \\ & 548 \\ \mathrm{C}_{38} & 558 \\ & 560 \\ \mathrm{C}_{39} & 562 \\ & 572 \\ & 574 \\ & 576 \\ & 586\end{array}$

No. of
double bonds
0
1
0
2
1
0
2
1
0
2
1
0
2
1
0
2
1
0
2
1
0
2
1
0
2
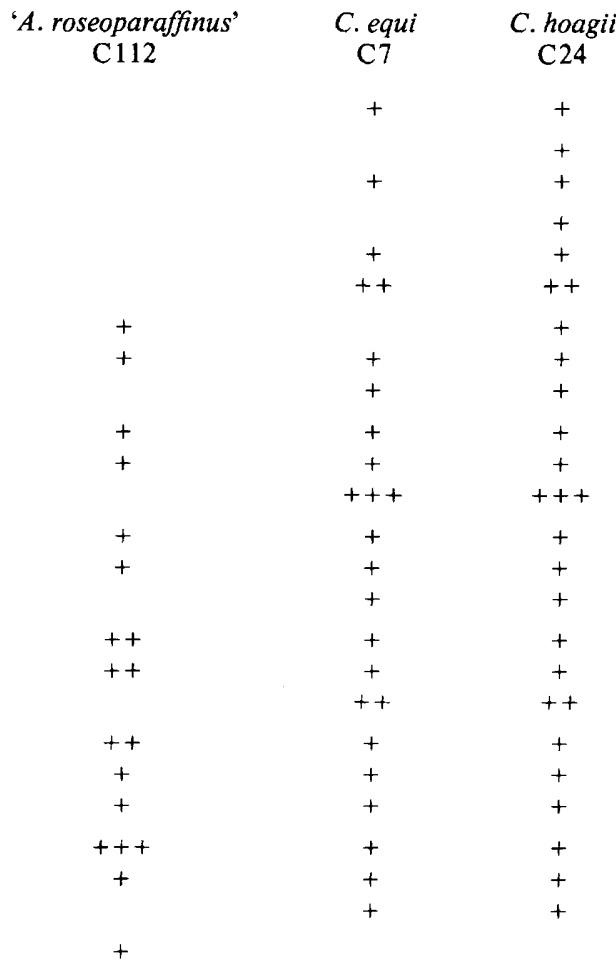

saturated, mono- and diunsaturated components were present in all strains (Table 4). The mycolates of the majority of these strains contained predominantly saturated $\mathrm{C}_{14}$ side-chains, although smaller amounts of saturated $C_{12}, C_{13}, C_{15}$ and $C_{16}$ and monounsaturated $C_{14}$ and $\mathrm{C}_{16}$ side-chains were occasionally detected (Table 2 ). The present data are in good agreement with the report of the release of a $\mathrm{C}_{16: 0}$ ester from the mycolates of $C$. pseudotuberculosis on pyrolysis gas chromatography (Lechevalier et al., 1973). Similarly, Diara \& Pudles (1959) described a saturated $\mathrm{C}_{34}$ mycolic acid in C. pseudotuberculosis which on pyrolysis released a $\mathrm{C}_{16: 0}$ ester. Yano \& Saito (1972), however, reported the presence of mycolic acids in ' $C$. ulcerans' having a shorter chain length $\left(\mathrm{C}_{20}\right.$ to $\left.\mathrm{C}_{32}\right)$ than those observed in the present study.

Strains of the animal-associated species $C$. pseudodiphtheriticum and C.xerosis contained mycolic acids with carbon ranges from $C_{28}$ to $C_{36}$ (Table 4). Mass spectrometry of the mycolates of $C$. pseudodiphtheriticum showed the predominance of saturated $\mathrm{C}_{12} \mathrm{H}_{25}$ side-chains $\mathrm{R}_{1}$; smaller amounts of saturated $\mathrm{C}_{14} \mathrm{H}_{29}$ and monounsaturated $\mathrm{C}_{14} \mathrm{H}_{27}$ and $\mathrm{C}_{16} \mathrm{H}_{31}$ side-chains were also detected (Table 2). Considerable variation in the composition of the side-chains was observed between strains of $C$. xerosis. The mycolates of $C$. xerosis strain C33 contained major amounts of saturated $\mathrm{C}_{12} \mathrm{H}_{25}$ and $\mathrm{C}_{14} \mathrm{H}_{29}$ and monounsaturated $\mathrm{C}_{14} \mathrm{H}_{27}$ and $\mathrm{C}_{16} \mathrm{H}_{31}$ side-chains, whereas those from $\mathrm{C}$. xerosis strains $\mathrm{C} 27$ and $\mathrm{C} 137 \mathrm{had}$ predominantly saturated $\mathrm{C}_{14} \mathrm{H}_{29}$ side-chains (Table 2, Fig. 3). Welby-Gieusse et al. (1970) found mycolic acids with one double bond in the $\alpha$-alkyl branch in a strain of $C$. pseudodiphtheriticum. These mycolates had a carbon chain length of $C_{32}$ to $C_{36}$ which on 
pyrolysis yielded $\mathrm{C}_{16: 0}, \mathrm{C}_{16: 1}, \mathrm{C}_{18: 0}$ and $\mathrm{C}_{18: 1}$ esters. In a strain of $C$. xerosis, Alshamaony $e t$ al. (1977) and Corina \& Sesardic (1980) found mycolic acids with carbon ranges of $C_{32}$ to $\mathrm{C}_{36}$ and $\mathrm{C}_{28}$ to $\mathrm{C}_{36}$, respectively.

The mycolic acids from 'C. flavidum', 'C. mycetoides' and 'C. segmentosum' had carbon ranges from $\mathrm{C}_{28}$ to $\mathrm{C}_{36}$ (Table 4). Mass spectrometry of the mycolates of ' $C$. flavidum' and ' $C$. segmentosum' showed the predominance of monounsaturated $C_{16}$ side-chains $R_{1}$; smaller amounts of saturated $\mathrm{C}_{12}$ and $\mathrm{C}_{14}$ side-chains were also detected (Table 2). In contrast, the mycolates of 'C . mycetoides' had major amounts of side-chains with compositions $\mathrm{C}_{14} \mathrm{H}_{29}$ and $\mathrm{C}_{15} \mathrm{H}_{31}$; smaller amounts of $\mathrm{C}_{12}, \mathrm{C}_{13}$ and $\mathrm{C}_{16}$ side-chains were also observed in the mass spectrum. The occurrence of major amounts of mycolic acids with side-chains containing odd numbers of carbon atoms was very characteristic and distinguished this taxon from all other coryneform bacteria examined (Table 2).

Strains of the glutamic acid-producing coryneform bacteria - 'Arthrobacter albidus', Brevibacterium ammoniagenes, 'B. chang-fua', B. divaricatum, 'B. flavum', 'B. glutamigenes', ' $B$. immariophilum', ' $B$. lactofermentum', 'B. roseum', 'B. saccharolyticum', 'B. taipei', 'Corynebacterium acetoacidophilum', C. callunae, C. glutamicum, 'C. herculis', C. lilium, 'C. melassecola' and 'Microbacterium ammoniaphilum' - all contained mycolic acids with carbon ranges of $\mathrm{C}_{28}$ to $\mathrm{C}_{36}$; saturated mono- and diunsaturated components were detected. Minor variations in the composition of the side-chains $R_{1}$ were observed between individual strains although the general homogeneity exhibited by the mycolic acids of the glutamic acid-producing strains supports their assignment to the genus Corynebacterium sensu stricto (Abe et al., 1967; Bousfield \& Goodfellow, 1976; Collins et al., 1979a).

The mycolic acids of strains bearing the labels $A$. variabilis, $B$. stationis and 'Microbacterium flavum' had carbon ranges of $\mathrm{C}_{28}$ to $\mathrm{C}_{36}$, composed of saturated, mono- and diunsaturated components. Barksdale et al. (1979) recently reported the presence of short-chain mycolic acids in 'Microbacterium flavum' and reclassified this species in the genus Corynebacterium, as $C$. flavescens. The results of the present study are in accord with this proposal. Keddie \& Cure (1977) reported the presence of free mycolic acids in $A$. variabilis and $B$. stationis strains which had chromatographic mobilities compatible with their inclusion in the genus Rhodococcus. In contrast, Goodfellow et al. (1976) reported that the mycolates obtained from whole-organism methanolysates of $A$. variabilis and $B$. stationis had chromatographic properties similar to those from true corynebacteria. The present data confirm that $A$. variabilis and $B$. stationis have mycolic acids with chain lengths similar to those from true corynebacteria.

The mycolic acids from 'A. roseoparaffinus', $C$. equi and $C$. hoagii exhibited carbon chain lengths of $\mathrm{C}_{33}$ to $\mathrm{C}_{39}, \mathrm{C}_{30}$ to $\mathrm{C}_{38}$ and $\mathrm{C}_{30}$ to $\mathrm{C}_{38}$, respectively (Table 6). On mass spectrometry the mycolates of ' $A$. roseoparaffinus' released major amounts of $\mathrm{C}_{16: 0}$ esters, although smaller peaks due to $\mathrm{C}_{14: 0}, \mathrm{C}_{15: 0}, \mathrm{C}_{16: 1}, \mathrm{C}_{17: 0}, \mathrm{C}_{18: 0}$ and $\mathrm{C}_{18: 1}$ esters were also detected. In contrast, the mycolates of $C$. equi and $C$. hoagii produced predominant amounts of $C_{14: 0}$ and $C_{16: 0}$ esters with small amounts of $\mathrm{C}_{12}, \mathrm{C}_{15}, \mathrm{C}_{17}$ and $\mathrm{C}_{18}$ esters also detected. The taxonomic position of ' $A$. roseoparaffinus', $C$. equi and $C$. hoagii remains problematic, as the chain length of their mycolates overlapped in size with those from representatives of Corynebacterium sensu stricto $\left(\mathrm{C}_{22}-\mathrm{C}_{36}\right)$ and Rhodococcus $\left(\mathrm{C}_{32}-\mathrm{C}_{66} ;\right.$ Minnikin \& Goodfellow, 1976, 1980). Other criteria, such as the presence of 10-methyloctadecanoic acid (tuberculostearic acid) in 'A. roseoparaffinus', C. equi and C. hoagii (D. E. Minnikin, M. D. Collins \& M. Goodfellow, unpublished results), indicate these taxa have a greater affinity with members of the genus Rhodococcus than with Corynebacterium sensu stricto; however, Keddie \& Cure (1977) did not detect free mycolic acids in this strain of 'A. roseoparaffinus'.

Representative strains of Caseobacter polymorphus have mycolic acids with carbon ranges between $\mathrm{C}_{30}$ and $\mathrm{C}_{36}$ (Table 4). The taxonomic position of this taxon remains unclear, for while the mycolic acid data indicate an affinity to true corynebacteria, the guanine plus cytosine content $(65 \cdot 5-66.9 \% \mathrm{G}+\mathrm{C}$; Crombach, 1978) suggests a closer relationship to the 
rhodococci. Clearly, further comparative studies are required to determine the detailed relationships that exist between caseobacters, corynebacteria and rhodococci.

Mycolic acids with a similar range of molecular weights to those from rhodococci were isolated from a number of differently labelled coryneform strains (Table 5). Thus, ' $A$. hydrocarboglutamicus', 'A. paraffineus', $A$. picolinophilus, 'B. butanicum' and ' $B$. healii' contained mycolic acids with carbon ranges from $C_{32}$ to $C_{46}$, 'B. ketoglutamicum' from $C_{38}$ to $\mathrm{C}_{51}$, 'B. paraffinolyticum' from $\mathrm{C}_{30}$ to $\mathrm{C}_{44}$, 'B. sterolicum' from $\mathrm{C}_{30}$ to $\mathrm{C}_{48}$, 'C. alkanum' from $\mathrm{C}_{34}$ to $\mathrm{C}_{46}$, 'C. hydrocarboclastus' from $\mathrm{C}_{32}$ to $\mathrm{C}_{46}$, 'Mycobacterium lacticolum' from $\mathrm{C}_{42}$ to $\mathrm{C}_{56}$ and 'Mycobacterium rubrum subsp. propanicum' from $\mathrm{C}_{36}$ to $\mathrm{C}_{50}$. Mycolic acids with a similar range of molecular weights $\left(C_{32}\right.$ to $\left.C_{44}\right)$ have been isolated from a strain of 'Mycobacterium paraffinicum' (Krasilnikov et al,, 1972). The same workers reported the isolation of short-chain mycolates $\left(\mathrm{C}_{30}\right.$ to $\left.\mathrm{C}_{34}\right)$ from a strain labelled 'Mycobacterium lacticolum var. aliphaticum' (Krasilnikov et al., 1973). Bousfield \& Goodfellow (1976) suggested that ' $B$. sterolicum' might be accommodated in the genus Rhodococcus; the mycolic acid data support this view. Furthermore, the mycolate data indicate that strains labelled 'A. hydrocarboglutamicus', 'A. paraffineus', $A$. picolinophilus, 'B. butanicum', $B$. healii', 'B. ketoglutamicum', 'B. paraffinolyticum', 'C. alkanum', 'C. hydrocarboclastus', 'Mycobacterium lacticolum' and 'Mycobacterium rubrum subsp. propanicum' should be reclassified in the genus $R$ hodococcus.

Recently, Goodfellow \& Alderson (1977) have reclassified strains of $C$. fascians and $C$. rubrum in the genus Rhodococcus. The presence of parent mycolic acids with carbon ranges of $\mathrm{C}_{38}$ to $\mathrm{C}_{52}$ in both $C$. fascians and C. rubrum strains (Table 5) is in accordance with this proposal, as representatives of the genus $R$ hodococcus have mycolates within the range $\mathrm{C}_{30}$ to $\mathrm{C}_{66}$ (Minnikin \& Goodfellow, 1976, 1980).

The results of both the present investigation and earlier studies (Goodfellow et al., 1976; Keddie \& Cure, 1977) show that mycolic acid analyses can make an important contribution to coryneform systematics. In particular, the results of the present lipid analyses add to the case for restricting the genus Corynebacterium to the human and animal corynebacteria and related saprophytic strains (Barksdale, 1970; Schleifer \& Kandler, 1972; Jones, 1975). Thus, the presence of short-chain mycolates $\left(\mathrm{C}_{22}\right.$ to $\left.\mathrm{C}_{36}\right)$ within the animal corynebacteria and related saprophytic strains such as $C$. glutamicum distinguishes these organisms from those in other coryneform taxa such as Arthrobacter, Brevibacterium, Cellulomonas, Curtobacterium, Microbacterium and Oerskovia which lack these characteristic lipids. Members of the genus Rhodococcus generally have larger mycolic acids $\left(C_{30}\right.$ to $\left.C_{66}\right)$ although a clear distinction between true corynebacteria and rhodococci cannot, at present, be made by analysis of mycolic acids alone.

The authors are indebted to Mr P. Kelly for mass spectroscopy. M.D.C. gratefully acknowledges receipt of a Luccock Scholarship awarded by the Medical Scholarships and Research Committee, Faculty of Medicine, University of Newcastle upon Tyne.

\section{REFERENCES}

Abe, S., Takayama, K. \& Kinoshita, S. (1967). Taxonomical studies on glutamic acid-producing bacteria. Journal of General and Applied Microbiology 13, 279-301.

Alshamaony, L., Goodfellow, M. \& Minnikin. D. E. $(1976 a)$. Free mycolic acids as criteria in the classification of Nocardia and the 'rhodochrous' complex. Journal of General Microbiology 92. 188-199.

Alshamaony, L., Goodfellow, M., Minnikin, D. E. \& Mordarska, H. (1976b). Free mycolic acids as criteria in the classification of Gordona and the 'rhodochrous' complex. Journal of General Micro biology 92, 183-187.

Alshamaony, L., Goodfellow, M., Minnikin, D. E., Bowden, G. H. \& Hardie, J. M. (1977). Fatty and mycolic acid composition of Bacterionema matruchotii and related organisms. Journal of General Microbiology 98, 205-213.

BARKSDALE, L. (1970). Corynebacterium diphtheriae and its relatives. Bacteriological Reviews 34. 378-. 422.

Barksdale, L., Lanéelle, M.-A., Pollice, M. C., Asselineau, J., Welby, M. \& Norgard, M. 
(1979). Biological and chemical basis for the reclassification of Microbacterium flavum OrlaJensen as Corynebacterium flavescens nom. rev. International Journal of Systematic Bacteriology 29, 222-233.

Beaman, B. L., Kris, K. S., Lanéelle, M.-A. \& BARKSDALE, L. (1974). Chemical characterization of organisms isolated from leprosy patients. Journal of Bacteriology 117, 1320-1324.

Bousfield, I. J. \& Goodfellow, M. (1976). The 'rhodochrous' complex and its relationship with allied taxa. In The Biology of the Nocardiae, pp. 39-85. Edited by M. Goodfellow, G. H. Brownell \& J. A. Serrano. London: Academic Press.

Camprell, I. M. \& Naworal, J. (1969). Mass spectral discrimination between monoenoic and cyclopropanoid, and between normal, iso and anteiso fatty acid methyl esters. Journal of Lipid Research 10, 589-592.

Collins, M. D. \& Jones, D. (1980). Lipids in the classification and identification of coryneform bacteria containing peptidoglycans based on 2,4diaminobutyric acid. Journal of Applied Bacteriology 48, 459-470.

Collins, M. D., Pirouz, T., Goodfellow, M. \& Minnikin, D. E. (1977). Distribution of menaquinones in actinomycetes and corynebacteria. Journal of General Microbiology 100, 221-230.

Collins, M. D., Goodfellow, M. \& Minnikin, D. E. $(1979 a)$. Isoprenoid quinones in the classification of coryneform and related bacteria. Journal of General Microbiology 110, 127-136.

Collins, M. D., Jones, D., Goodfellow, M. \& Minnikin, D. E. $(1979 b)$. Isoprenoid quinone composition as a guide to the classification of Listeria, Brochothrix, Erysipelothrix and Caryophanon. Journal of General Microbiology 111, 453-457.

Collins, M. D., Goodfellow, M. \& Minnikin, D. E. (1980). Fatty acid, isoprenoid quinone and polar lipid composition in the classification of Curtobacterium and related taxa. Journal of General Microbiology 118, 29-37.

Corina, D. L. \& Sesardic, D. (1980). Profile analysis of total mycolic acids from skin corynebacteria and from named Corynebacterium strains by gas-liquid chromatography and gas-liquid chromatography/ mass spectrometry. Journal of General Microbiology 116, 61-68.

Crombach, W. H. J. (1972). DNA base composition of soil arthrobacters and other coryneforms from cheese and sea fish. Antonie van Leeuwenhoek 29, 344-358.

Сrombach, W. H. J. (1978). Caseobacter polymorphus gen. nov., sp. nov., a coryneform bacterium from cheese. International Journal of Systematic Bacteriology 28, 354-366.

DiarA, A. \& Pudles, J. (1959). Sur les lipides de Corynebacterium ovis. Bulletin de la Société de chimie biologique 41, 481-486.

ETÉmAdi, A. H. (1967). The use of pyrolysis gas chromatography and mass spectroscopy in the study of the structure of mycolic acids. Journal of Gas Chromatography 5, 447-456.

Goodfellow, M. \& Alderson, G. (1977). The actinomycete-genus Rhodococcus: a home for the 'rhodochrous' complex. Journal of General Microbiology 100, 99-122.

Goodfellow, M., Collins, M. D. \& Minnikin, D. E. (1976). Thin-layer chromatographic analysis of mycolic acid and other long-chain components in whole-organism methanolysates of coryneform and related taxa. Journal of General Microbiology 96, 351-358.

Goodfellow, M., Orlean, P. A. B., Collins, M. D., Alshamaony, L. \& Minnikin, D. E. (1978). Chemical and numerical taxonomy of strains received as Gordona aurantiaca. Journal of General Microbiology 109, 57-68.

JONES, D. (1975). A numerical taxonomic study of coryneform and related bacteria. Journal of General Microbiology 87, 52-96.

JONES, D. (1978). An evaluation of the contributions of numerical taxonomic studies to the classification of coryneform bacteria. In Coryneform Bacteria, pp. 13-46. Edited by I. J. Bousfield \& A. G. Callely. London: Academic Press.

Keddie, R. M. \& Bousfield, I. J. (1980). Cell wall composition in the classification and identification of coryneform bacteria. In Microbiological Classification and Identification, pp. 167-188. Edited by M. Goodfellow \& R. G. Board. London: Academic Press.

Keddie, R. M. \& Cure, G. L. (1977). The cell wall composition and distribution of free mycolic acids in named strains of coryneform bacteria and in isolates from various natural sources. Journal of Applied Bacteriology 42, 229-252.

Keddie, R. M. \& Cure, G. L. (1978). Cell wall composition of coryneform bacteria. In Coryneform Bacteria, pp. 47-83. Edited by I. J. Bousfield \& A. G. Callely. London: Academic Press.

Krasilnikov, N. A., Koronelli, T. V. \& Rozynov, B. A. (1972). Aliphatic and mycolic acids of Mycobacterium paraffinicum. Mikrobiologiya 41, 808-812.

Krasilnikov, N. A., Koronelli, T. V., Rozynov, B. A. \& KalyUzhnAYA, T. V. (1973). Mycolic acids of pigmented paraffin-oxidizing mycobacteria. Mikrobiologiya 42, 240-243.

Lechevalier, M. P., Lechevalier, H. A. \& Horan, A. C. (1973). Chemical characteristics and the classification of nocardiae. Canadian Journal of Microbiology 19, 965-972.

Maurice, M. T., Vacheron, M. J. \& Michel, G. (1971). Isolement d'acides nocardiques de plusiers espèces de Nocardia. Chemistry and Physics of Lipids 7, 9-18.

Minnikin, D. E. \& Goodfellow, M. (1976). Lipid composition in the classification and identification of nocardiae and related taxa. In The Biology of the Nocardiae, pp. 160-219. Edited by M. Goodfellow, G. H. Brownell \& J. A. Serrano. London: Academic Press.

Minnikin, D. E. \& Goodfellow, M. (1980). Lipid composition in the classification and identification of acid-fast bacteria. In Microbiological Classification and Identification, pp. 189-256. Edited by $\mathrm{M}$. Goodfellow \& R. G. Board. London: Academic Press.

Minnikin, D. E., Alshamaony, L. \& Goodfellow, M. (1975). Differentiation of Mycobacterium, 
Nocardia and related taxa by thin-layer chromatographic analysis of whole-organism methanolysates. Journal of General Microbiology 88, 200-204.

Minnikin, D. E., Goodfellow, M. \& Collins, M. D. (1978). Lipid composition in the classification and identification of coryneform and related taxa. In Coryneform Bacteria, pp. 85-160. Edited by I. J. Bousfield \& A. G. Callely. London: Academic Press. Minnikin, D. E., Collins, M. D. \& Goodfellow, M. (1979). Fatty acid and polar lipid composition in the classification of Cellulomonas, Oerskovia and related taxa. Journal of Applied Bacteriology 47, 87-95.

Oxazaki, H., Sugino, H., Kanzaki, T. \& Fukuda, H. (1969). L-Glutamic acid fermentation. VI. Structure of a sugar lipid produced by Brevibacterium thiogenitalis. Agricultural and Biological Chemistry 33, 764-770.

SChleifer, K. H. \& Kandler, O. (1972). Peptidoglycan types of bacterial cell walls and their taxonomic implications. Bacteriologial Reviews 36, 407-477.

Senn, M., Ioneda, T., Pudles, J. \& Lederer, E. (1967). Spectrometrie de masse de glycolipids I. Structure du 'cord factor' de Corynebacterium diphtheriae. European Journal of Biochemistry 1, 353-356.

Skerman, V. B. D., McGowan, V. \& Sneath, P. H.
A. (editors) (1980). Approved Lists of Bacterial Names. International Journal of Systematic Bacteriology 30, 225-420.

Starr, M. P., Mandel, M. \& Murata, M. (1975). The phytopathogenic coryneform bacteria in the light of DNA base composition and DNA-DNA segmental homology. Journal of General and Applied Microbiology 21, 13-26.

Suzuki, T., Tanaka, K., Matsubara, I. \& Kinoshita, S. (1969). Trehalose lipid and $\alpha$ branched- $\beta$-hydroxy fatty acid formed by bacteria grown on n-alkanes. Agricultural and Biological Chemistry 33, 1619-1627.

Welby-Gieusse, M., LANÉElle, M. A. \& AsselineaU, J. (1970). Structure des acides corynomycoliques de Corynebacterium hofmanii et leur implication biogénétique. European Journal of Biochemistry 13, 164-167.

YAMADA, Y., INOUYE, G., TAHARA, Y. \& Kondo, K. (1976). The menaquinone system in the classification of coryneform and nocardioform bacteria and related organisms. Journal of General and Applied Microbiology 22, 203-214.

YANO, I. \& SAITO, K. (1972). Gas chromatographic and mass spectrometric analysis of molecular species of corynomycolic acids from Corynebacterium ulcerans. FEBS Letters 23, 352-356. 